\title{
TOTAL DISSOLVED INORGANIC CARBON AND PHYSICOCHEMICAL CHARACTERISTICS OF SURFACE MICROLAYER AND UPPER MIXED LAYER WATER FROM LAGOS LAGOON, NIGERIA
}

\author{
BENSON N.U (,* $^{*}$ \\ ADEDAPO A.E. ${ }^{1}$ \\ ERITOBOR A.L. ${ }^{2}$ \\ UDOSEN E.D. ${ }^{3}$
}

\author{
${ }^{1}$ Department of Chemistry, College of Science and Technology \\ Covenant University, P.M.B. 1023, Ota, Nigeria \\ ${ }^{2}$ School of Environmental and Horticultural Studies \\ Niagara College, NL Campus, 135 Taylor Road, Ontario, Canada \\ ${ }^{3}$ Department of Chemistry, University of Uyo \\ P.M.B. 1017, Uyo, Akwa Ibom State, Nigeria
}

Received: 30/04/2014

Accepted: 11/05/2015

Available online: 13/05/2015 *to whom all correspondence should be addressed: e-mail: nsikak.benson@cu.edu.ng

\section{ABSTRACT}

The carbonate and physicochemical characteristics of the surface microlayer and upper mixed layer of a tropical coastal lagoon were investigated. Data on the physicochemical parameters generally indicated a moderately polluted ecosystem. The influence of the ocean environment over the Lagoon system was evident by elevated salinity levels. The mean total dissolved inorganic carbon (DIC) for the surface microlayer (SML) and subsurface water (SSW) samples were 2626.6 and $2550.9 \mu \mathrm{mol} \mathrm{kg}{ }^{-1} \mathrm{SW}$ respectively. The dominant inorganic form of DIC in the lagoon water samples was $\mathrm{HCO}_{3}{ }^{-}$with a calculated average abundance $>95.4 \%$ in the SML and $>94 \%$ in the SSW. The bicarbonate species derived abundance varied between $1.6 \%(\mathrm{SML})$ and 8.4\% (SSW), while the aqueous carbon dioxide were generally low in percentages ranging from 0.4 in SSW to 1.5 in SML water samples. In general, the occurrence of the carbonate species was in the order $\mathrm{HCO}_{3}{ }^{-}>\mathrm{CO}_{3}{ }^{2-}$ $>\mathrm{CO}_{2}$. Results showed that total alkalinity $\left(\mathrm{A}_{\mathrm{T}}\right)$ was relatively greater than the DIC. Long term monitoring studies in the coastal lagoon systems is needed to understand the coastal water chemistry and pollution status.

Keywords: Carbonate quantities; physicochemical properties; surface microlayer; upper mixed layer; coastal lagoon

\section{Introduction}

In recent years, concerns have been expressed over the deteriorating state of the world's coastal and inland aquatic ecosystems due to increasing stress arising from the unregulated dumping of untreated sewage, toxic effluents, untreated industrial and urban wastes, excessive nutrient loadings, medicinal residues, fertilizers and chemical run-offs and crude oil pollution. This environmental problem - water pollution - is further exacerbated by consequential episodic losses of living marine biodiversity and resources, and irreversible degradation of these vulnerable ecosystems. Coastal lagoons and lacustrine ecosystems are under increasing threat of pollution by biological, physical and chemical contaminants that emanate mainly from 
anthropogenic sources. It has been reported that the primary productivity and usability of a surface water system is a function of its physicochemical characteristics (Agbaire and Obi, 2009; Raibole and Singh, 2011; Lawson, 2011; Gupta et al., 2013, Ezeonyejiaku and Obiakor, 2013; Omaka et al., 2014). Several studies have indicated that physicochemical properties could be used as significant markers in water pollution studies as well as evaluate the quality status of an aquatic ecosystem (Valente et al. 1997; Udosen, 2001; Raj and Azeez 2009; Williams and Benson, 2010). Aside water pollution concerns, coastal seawater and estuarine ecosystems are increasingly becoming important storehouses of atmospheric carbon dioxide $\left(\mathrm{CO}_{2}\right)$.

Anthropogenic $\mathrm{CO}_{2}$ emissions come from fossil fuel consumption and other multiple sources such as cement production and land use change. These human mediated activities have contributed significantly to the amount of carbon dioxide in the atmosphere resulting in enhanced levels of atmospheric $\mathrm{CO}_{2}$ from about 280 ppm in 1850 to concentrations over 400 ppm in April 2010 (Thompson, 2014). It has been reported that over $50 \%$ of $\mathrm{CO}_{2}$ from fossil fuel consumption is retained in the atmosphere while the oceans, seas, rivers and the terrestrial biosphere serve as natural sinks for the remaining percent. In recent years, there has been an increasing interest in seawater measurements of $\mathrm{CO}_{2}$ and related air-water exchange of $\mathrm{CO}_{2}$ (Muduli et al., 2012; Newton et al., 2014; Bockmon and Dickson, 2015). These measurements which are either direct or indirect aim to evaluate the levels of dissolved inorganic carbon and better explore the response of the world aquatic ecosystems to the fast changing atmospheric $\mathrm{CO}_{2}$ levels and to climate change (Takahashi et al., 1997; Muduli et al., 2013).

Lagos Lagoon is a major and commercially important coastal marine ecosystem in Nigeria. It is a highly stressed coastal lagoon due to a combination of urbanization, industrialization and multifaceted developmental pressures. The Lagoon system is also subjected to accidental and intentional domestic wastes such as industrial effluents, municipal inputs and crude oil spillage, (which arises from pipe lines leakage, accidental spills from tankers, wastewater from industries among others). Oil pollution into the Lagos Lagoon arises from multiple human-induced sources including pipeline leakages, accidental spills from tankers, industrial wastewater, among others. For more than four decades, various multinational companies operating onshore and offshore the coastal environment in Nigeria have undertaken the exploitation of the vast crude oil resources especially along the coastline and marine systems. Following this, the country's coastal aquatic ecosystems have been consistently exposed to increasing ecological and toxicological problems owing to diverse pollutants released into them. Lagoons and estuaries by their nature are highly fragile habitats. Therefore, it is imperative to ascertain and characterise their pollution statuses especially taking into consideration the surface microlayer and subsurface components of the water system.

The surface microlayer (SML) is the thin layer in the top of the seawater column, with thickness from few micrometers to $1 \mathrm{~mm}$. It is known to serve as a sink and source of marine pollutants and also plays an important role in a number of biogeochemical and ecological processes such as air-sea exchanges of gases and aerosols, synthesis, transformation and cycling of organic substances, and accumulation and degradation of pollutants (Del Vento and Dachs, 2007; Guitart et al., 2007; Gioia et al., 2011; Cunliffe et al., 2013; Ya et al., 2014; Benson et al., 2014). This paper presents an investigation on the physicochemical and carbonate characteristics of surface microlayer and subsurface water of Lagos Lagoon in Nigeria.

\section{Materials and method}

\subsection{Description of study area}

Lagos Lagoon $\left(6^{\circ} 27^{\prime} \mathrm{N} 3^{\circ} 23^{\prime} \mathrm{E}\right)$ is an aquatic ecosystem, strategically located within the Lagos metropolis, cutting across the southern part of the metropolis, and links the Atlantic Ocean (in the west and south) and Lekki Lagoon (in the east). It is about $6354.788 \mathrm{~km}^{2}$ in surface area, and about $50 \mathrm{~km}$ long and $3-13 \mathrm{~km}$ wide. The lagoon is divided into the Epe Division, the Lagos Harbor, and the Metropolitan segments. It discharges 
into the Atlantic Ocean through the Lagos Harbor. A significant near-shore portion of the Lagoon is home to local fishermen, industries and other developmental establishments. In recent years, it has been extensively exploited for marine transportation and also a dumpsite for untreated industrial and urban wastes. In addition to the discharge of untreated wastewater into the Lagoon from manufacturing industries dotted along the coastline, wood shavings, domestic sewage, garbage, medical residues and oil pollution are point sources of concern.

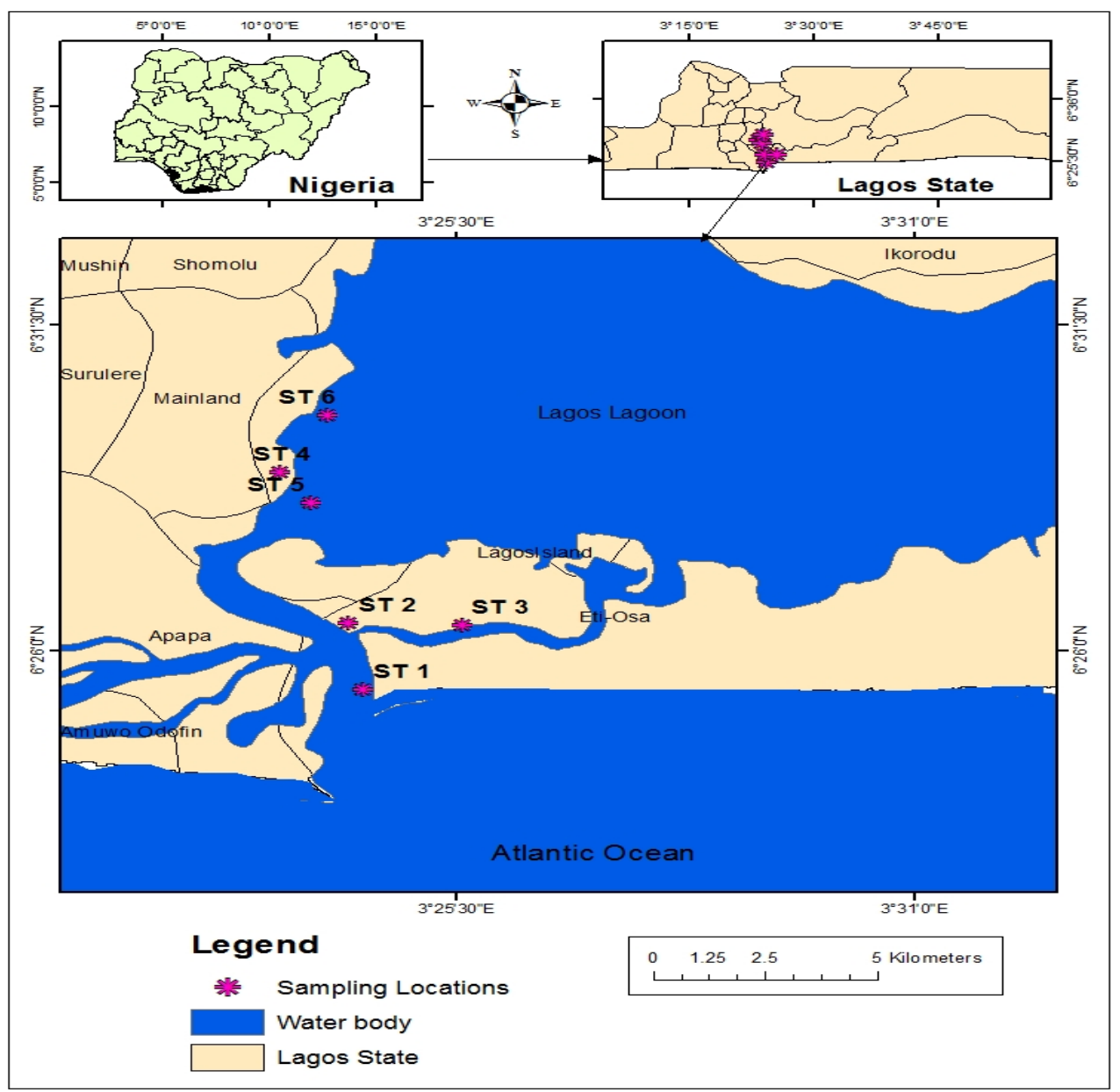

Figure 1. Map of Lagos Lagoon showing the sampling locations. Inset: Map of Nigeria and Lagos State showing the study area

\subsection{Sample collection and pre-treatment}

Samples of water from the surface microlayer and upper mixed layer of the Lagos Lagoon were taken from six designated locations (Oceanography jetty ST1, Bonny camp ST2, Falomo bridge ST3, Apapa ST4, Ijora ST5, and Okobaba ST6). The SML samples were collected using improvised screen sampler and $1.7 \mathrm{~L}$ Niskin water sampler (Model $60.002 \mathrm{KC}$-Denmark A/S). The screen sampler consists of the screen (a wire mesh of about 10 to 16 wires per inch), two handles attached to a framework, which supports this screen having a dimension of 65 by $45 \mathrm{~cm}$. Microlayer water samples were collected by holding the rectangular screen by its handles in a horizontal position and parallel to the ocean surface for about 5 seconds after which the screen was withdrawn and then replaced. This was done several times before taking each sample in order to condition the screen wires to the chemical substance in the water. The screen was then withdrawn from beneath the 
surface of the water through the sea-air interface while still maintaining the horizontal position. As the screen is raised through the water below the surface, seawater merely flows between the wires and when passing through the surface, thin segment of the surface layer between the wires was then immediately tilted towards one rear corner of the frame, so that the collected surface water can drain into a glass collection container. On the other hand, subsurface layer water samples were collected using Niskin bottles lowered to 15 to 20 $\mathrm{cm}$.

The physicochemical properties of water samples such as conductivity, temperature, dissolved oxygen and $\mathrm{pH}$ were determined in situ immediately after each sample was collected. A portable HACH multiparameter meter (senION+ MM156 with multisensor) was used for in situ measurement of $\mathrm{pH}$, conductivity and temperature of the SML and SSW water samples. The dissolved oxygen levels were obtained using a portable YSI Pro20 dissolved oxygen meter. Turbidity was measured using a handheld turbidimeter (HACH Model 2100Q). The global positioning system (GPS) was used to take the coordinates of sampling locations. Prior to laboratory analysis, the water samples collected were stored in a clean, well-labeled glass bottles with lid at about $4^{\circ} \mathrm{C}$ and transported to the laboratory. In the laboratory, the water samples were stored in a refrigerator maintained at $4^{\circ} \mathrm{C}$ for a day. Total alkalinity $\left(\mathrm{A}_{T}\right)$ was determined by Gran titration method using the refrigerated and filtered $(0.2 \mu \mathrm{m})$ water samples.

\subsection{Data management and analysis}

CO2SYS was used for the calculation of carbonate system parameters such $\mathrm{pCO}_{2}$, bicarbonate $\left(\mathrm{HCO}_{3}^{-}\right)$, dissolved carbon dioxide $\left(\mathrm{CO}_{2}\right)$, carbonate $\left(\mathrm{CO}_{3}{ }^{2-}\right)$, fugacity of carbon dioxide $\left(f \mathrm{CO}_{2}\right)$, borate alkalinity (B Alk), etc. (Robbins et al., 2010). CO2calc is a user-friendly, stand-alone application developed by the U.S. Geological Survey Florida Shelf Ecosystems Response to Climate Change Project for the calculation of carbonate system parameters. The dissociation constants for carbonic acid $K_{1}$ and $K_{2}$ as determined by Mehrbach et al., (1973) and refit by Dickson and Millero (1987) were used for $\mathrm{CO}_{2}$ constants, while the $K_{s 04}$ reported by Dickson (1990) was used for $\mathrm{KHSO}_{4}$ dissociation. The seawater scale $\left(\mathrm{mol} \mathrm{kg}^{-1} \mathrm{SW}\right)$ was chosen as the $\mathrm{pH}$ scale. $\mathrm{CO}_{2}$ system parameters at the input conditions were physical (salinity, temperature) and carbonate data ( $\mathrm{pH}$ and total alkalinity $\left.\left(A_{T}\right), \mu \mathrm{mol} \mathrm{kg}{ }^{-1} \mathrm{SW}\right)$. Salinity and $A_{T}$ are important measurable quantities that can be used together with other quantities to calculate the concentrations of other species $\left(\mathrm{CO}_{2}, \mathrm{HCO}_{3}{ }^{-}, \mathrm{CO}_{3}{ }^{2-}, \mathrm{H}^{+}, \mathrm{OH}^{-}\right)$of the carbonate system (Wolf-Gladrow et al., 2007).

\section{Results and discussion}

\subsection{Physicochemical properties of Lagos Lagoon seawater}

The results of the physicochemical and carbonate parameters namely temperature, salinity, conductivity, $\mathrm{pH}$, turbidity, $\mathrm{pCO}_{2}$, bicarbonate $\left(\mathrm{HCO}_{3}^{-}\right)$, dissolved carbon dioxide $\left(\mathrm{CO}_{2}\right)$, carbonate $\left(\mathrm{CO}_{3}{ }^{2-}\right)$ and total dissolved inorganic carbon are presented in this section. $\mathrm{pH}$ represents the effective concentration (activity) of hydrogen ions $\left(\mathrm{H}^{+}\right)$in water. In natural water, the $\mathrm{pH}$ is usually between 6 and 9 , while that of normal seawater is 8.2. The measured $\mathrm{pH}$ of the surface microlayer and subsurface water samples from the Lagos Lagoon varied between 7.8 and 8.2 , and from 8.0 to 8.2 respectively. These fluctuations in $\mathrm{pH}$ might be controlled principally by the rate of photosynthesis, rate of respiration, and buffering capacity. However, the observed $\mathrm{pH}$ values for all designated locations were indicative of a typical seawater system (Fig. 2).

Temperature of water is a very important factor for aquatic life. It is known to influence key biogeochemical processes such as sea-air exchange of marine gases, the rate of metabolic and reproductive activities, and the concentration of dissolved oxygen especially within the epipellagic zone of the aquatic ecosystem. As expected the temperature of the SML was slightly higher than the SSW, which may be attributed to the direct exposure to radiation (heat). However, the measured temperatures within the Lagoon's surface microlayer 
and subsurface layer waters were relatively stable. The near uniformity of water temperatures may be linked to the shallowness of the Lagoon, which ensured a well-mixed system.

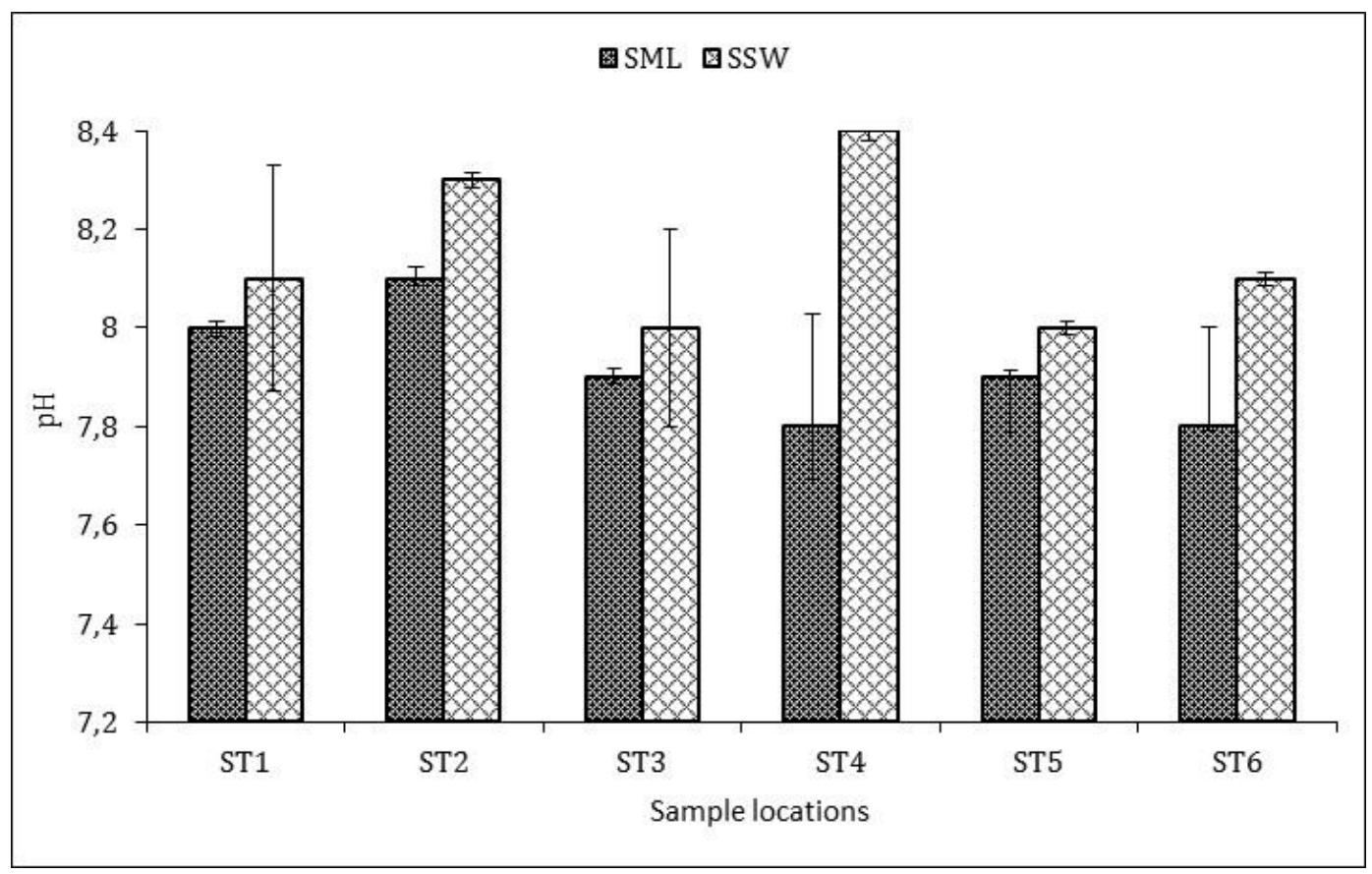

Figure 2. $\mathrm{pH}$ levels in surface microlayer (SML) and subsurface water (SSW) samples from designated locations in Lagos lagoon

Turbidity is an important water quality parameter that can indicate the presence of dispersed suspended solids, organic materials, algae and other microorganisms in the water column. The increase in turbidity especially within the surface microlayer implies that there will be less penetration of sunlight into the upper mixed layer of seawater (Williams and Benson, 2010). This has the potential of lowering primary production of an aquatic ecosystem. The observed turbidity at the designated locations within Lagos Lagoon was variable and varied between $9.0 \pm 0.04$ and $23.0 \pm 3.01$ NTU in the SML, while it ranged from $9.0 \pm 2.36$ to $41.0 \pm 8.00$ NTU in the SSW (Table 1).

Dissolved oxygen (DO) is a significant indicator of the health status of an aquatic ecosystem's ability to support life. The level of DO in water is governed by hydrological factors such as the amount of dissolved or suspended solids, nutrients, temperature, organic wastes and the type and quantity of organisms present. The measured DO in the surface microlayer and subsurface water samples from the Lagos Lagoon varied between $3.5 \pm 0.07$ and $7.8 \pm 0.08 \mathrm{mg} \mathrm{l}^{-1}$, and from $3.1 \pm 1.25$ to $6.8 \pm 0.40 \mathrm{mg} \mathrm{l}^{-1}$ respectively (Table 1 ). However, the observed levels of salinity recorded for surface microlayer water samples ranged between $23.6 \pm 5.22$ and $30.9 \pm 0.03$ PSU at ST $1_{S M L}$ and ST6 $6_{S M L}$ locations respectively (Table 1). The average salinity calculated for the Lagos Lagoon SML system in this study is 27.3 PSU, while the SSW samples recorded mean salinity level of 28.6 PSU. This implies that in every 1 liter of seawater from the Lagoon, an average of 27.3 and $28.6 \mathrm{~g}$ of salt will likely be present in the SML and SSW water respectively. Thus the influence of the Atlantic Ocean water over the Lagos Lagoon system was evident by elevated salinity levels. Salinity measurement is usually a function of the total salts that are dissolved in the water. The chemical ions that contribute to seawater salinity include chloride, sodium, sulfate, magnesium, calcium, potassium, bicarbonate, bromide, borate, strontium, and fluoride. However, in seawater systems, the degree of salinity is usually stable but variations could occur as a result of 
several factors such as the relative amount of evaporation (tends to increase salinity) or precipitation (decreases seawater salinity) (Anderson, 2008).

Table 1. Physicochemical properties of surface microlayer and subsurface water samples from Lagos Lagoon

\begin{tabular}{|c|c|c|c|c|c|c|}
\hline $\begin{array}{l}\text { Sample } \\
\text { location }\end{array}$ & Sample ID & $\begin{array}{l}\text { Temp } \\
\left({ }^{\circ} \mathrm{C}\right)\end{array}$ & $\begin{array}{l}\text { Salinity } \\
\text { (PSU) }\end{array}$ & $\begin{array}{l}\text { Turbidity } \\
\text { (NTU) }\end{array}$ & $\mathrm{DO}\left(\mathrm{mg} \mathrm{l}^{-1}\right)$ & $\begin{array}{c}\text { CDT } \\
\left(\mu \mathrm{S} \mathrm{cm}^{-1}\right)\end{array}$ \\
\hline $\begin{array}{c}\text { Oceanography } \\
\text { jetty }\end{array}$ & ST1 $1_{S M L}$ & 29.4 & $30.9 \pm 0.03$ & $15.0 \pm 1.17$ & $5.5 \pm 0.09$ & 47.3 \\
\hline $\begin{array}{l}06^{\circ} 25^{\prime} 14.0^{\prime \prime} \mathrm{N} \\
03^{\circ} 24^{\prime} 26.1^{\prime \prime} \mathrm{E}\end{array}$ & $\mathrm{ST} 1_{\text {sSW }}$ & 29.4 & $31.3 \pm 0.006$ & $17.0 \pm 0.53$ & $3.8 \pm 0.13$ & 47.8 \\
\hline Bonny camp & $\mathrm{ST} 2_{S M L}$ & 29.5 & $26.6 \pm 0.51$ & $9.0 \pm 0.82$ & $7.8 \pm 0.08$ & 41.5 \\
\hline $\begin{array}{l}06^{\circ} 26^{\prime} 27.2^{\prime \prime} \mathrm{N} \\
03^{\circ} 24^{\prime} 11.8^{\prime \prime} \mathrm{E}\end{array}$ & $\mathrm{ST} 2_{s S W}$ & 29.5 & $27.6 \pm 4.14$ & $9.0 \pm 2.36$ & $6.8 \pm 0.40$ & 43.0 \\
\hline Falomo bridge & ST3 $S M L$ & 29.6 & $24.8 \pm 5.09$ & $9.0 \pm 0.04$ & $6.2 \pm 1.08$ & 39.5 \\
\hline $\begin{array}{l}06^{\circ} 26^{\prime} 25.5^{\prime \prime} \mathrm{N} \\
03^{\circ} 25^{\prime} 33.7^{\prime \prime} \mathrm{E}\end{array}$ & ST3 ${ }_{s s w}$ & 29.3 & $29.9 \pm 0.27$ & $10.0 \pm 1.57$ & $4.8 \pm 0.15$ & 45.8 \\
\hline $\begin{array}{c}\text { Apapa } \\
06^{\circ} 28.060^{\prime} \mathrm{N}\end{array}$ & $\mathrm{ST} 4_{S M L}$ & 29.6 & $29.7 \pm 0.62$ & $15.0 \pm 1.83$ & $3.5 \pm 0.07$ & 45.6 \\
\hline $03^{\circ} 23.022^{\prime} \mathrm{E}$ & $\mathrm{ST}_{\text {ssw }}$ & 29.5 & $30.2 \pm 0.01$ & $38.0 \pm 9.52$ & $3.1 \pm 1.25$ & 46.0 \\
\hline $\begin{array}{c}\text { ljora } \\
06^{\circ} 28.49^{\prime} \mathrm{N}\end{array}$ & ST5 SML & 29.3 & $28.3 \pm 0.25$ & $15.0 \pm 0.16$ & $4.9 \pm 0.19$ & 43.3 \\
\hline $03^{\circ} 23.739^{\prime} \mathrm{E}$ & ST5 ssw & 29.3 & $28.6 \pm 2.03$ & $12.0 \pm 7.40$ & $5.8 \pm 0.06$ & 44.2 \\
\hline Okobaba & ST6 $S M L$ & 29.5 & $23.6 \pm 5.22$ & $23.0 \pm 3.01$ & $5.0 \pm 0.49$ & 37.4 \\
\hline $\begin{array}{l}06^{\circ} 29.424^{\prime} \mathrm{N} \\
03^{\circ} 23.739^{\prime} \mathrm{E}\end{array}$ & ST6 $_{\text {ssw }}$ & 29.5 & $24.0 \pm 6.04$ & $41.0 \pm 8.00$ & $3.3 \pm 0.13$ & 37.7 \\
\hline
\end{tabular}

DO = Dissolved Oxygen, CDT = Conductivity

\subsection{Carbonate properties of SML and SSW}

Total Alkalinity, $\mathrm{A}_{\mathrm{T}}$, is the measure of the amount of negatively charged ions $\left(\mathrm{HCO}_{3}{ }^{-}\right.$and $\left.\mathrm{CO}_{3}{ }^{2-}\right)$ available in a given amount of seawater. Typically, as the amount of dissolved bicarbonates and carbonates increase in seawater, the alkalinity increases. The observed $\mathrm{A}_{T}$ level in the Lagos Lagoon was relatively stable but however indicated slight variations in the SML and the upper mixed layer water. In this work, careful attention was given to the $A_{T}$ determinations because the data was used to calculate the amount of dissolved carbon dioxide gas $\left(p \mathrm{CO}_{2}\right), f \mathrm{CO}_{2}$, dissolved bicarbonates and carbonates (Table 2, Figs. 3,4) (Robbins et al. 2010).

$\mathrm{CO}_{2}$ is biogeochemically important in coastal marine systems and is known to exist in the form of a dissolved gas in mainly three inorganic forms: free aqueous carbon dioxide $\mathrm{CO}_{2}(\mathrm{aq})$, bicarbonate $\mathrm{HCO}_{3}{ }^{-}$, and carbonate ion $\mathrm{CO}_{3}{ }^{2-}$ (Zeebe, 2011; Ji et al., 2009). In practical terms, the sum of these dissolved carbonate species is commonly known as the total inorganic carbon (TIC), or dissolved inorganic carbon (DIC), or total dissolved inorganic carbon $\mathrm{TCO}_{2}$ (DOE, 1994; Weiss, 1974; Zeebe and Wolf-Gladrow, 2001) The mean $p \mathrm{CO}_{2}$ calculated for the surface microlayer water was $629.7 \mu$ atm, while the average $p \mathrm{CO}_{2}$ for the upper mixed layer was 381.0 $\mu a t m$. The derived DIC in the surface microlayer and subsurface water samples from the Lagos Lagoon varied between 2441.2 and $2807.5 \mu \mathrm{mol} \mathrm{kg}^{-1} \mathrm{SW}$, and from 2449.1 to $2734.4 \mu \mathrm{mol} \mathrm{kg}{ }^{-1} \mathrm{SW}$ respectively (Table 2). On the other hand, the mean DIC for the SML and SSW water samples were 2626.6 and $2550.9 \mu \mathrm{mol} \mathrm{kg}^{-1} \mathrm{SW}$ respectively.

The dominant inorganic form of DIC in the lagoon water samples was $\mathrm{HCO}_{3}{ }^{-}$with a calculated average abundance $>95.4 \%$ in the SML and $>94 \%$ in the SSW. The bicarbonate species derived abundance varied between $1.6 \%(\mathrm{SML})$ and $8.4 \%$ (SSW), while the aqueous carbon dioxide were generally low in percentages 
ranging from 0.4 in SSW to 1.5 in SML water samples. In general, the occurrence of the carbonate species was in the order $\mathrm{HCO}_{3}{ }^{-}>\mathrm{CO}_{3}{ }^{2-}>\mathrm{CO}_{2}$.

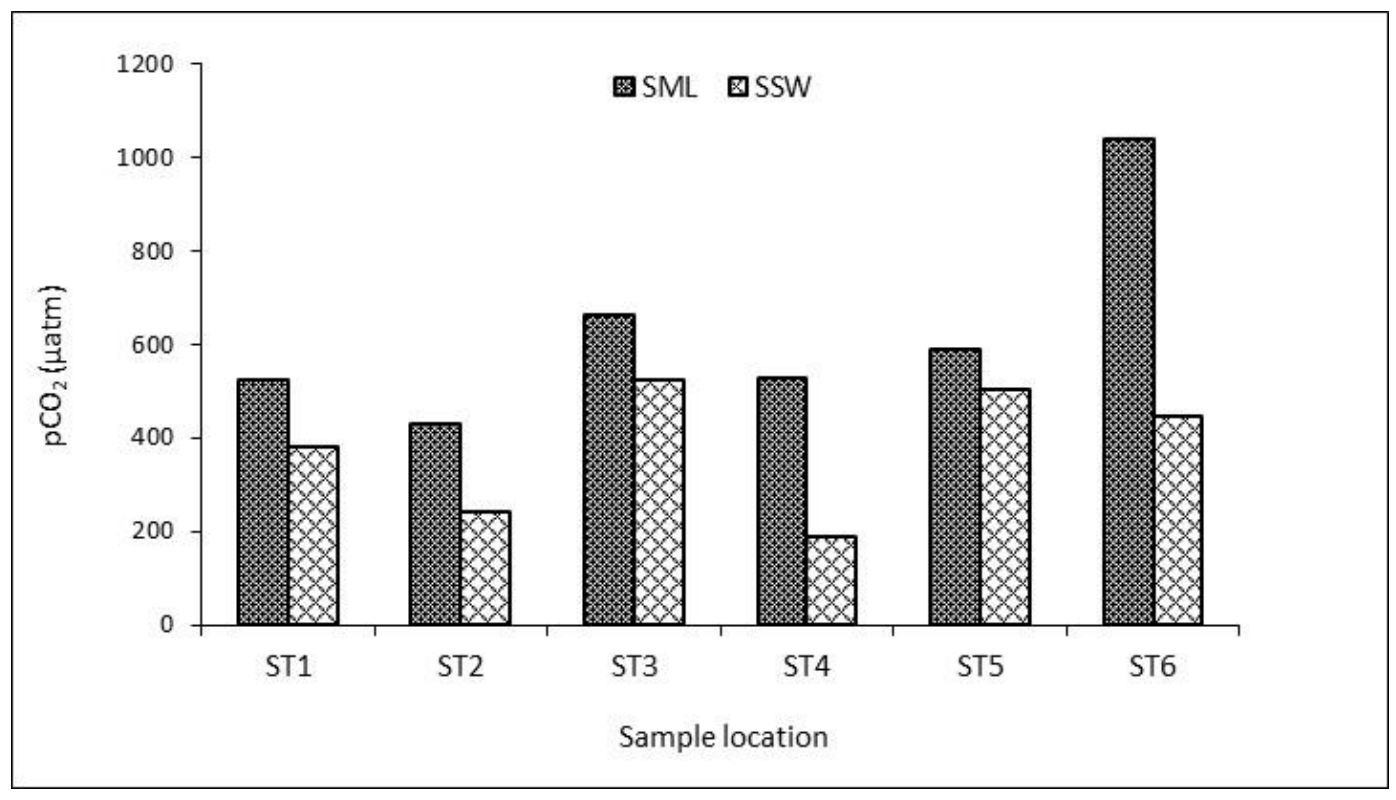

Figure 3. $p \mathrm{CO}_{2}$ levels in SML and SSW samples from Lagos Lagoon

The distributions of the total dissolved inorganic carbon in the SML at ST1 to ST5 were similar and those derived for the SSW were similar. However, values at one or two designated stations indicated slight increase in DIC, which might have been due to fresh water dilution or organic matter residues. The calculated DIC in this study were however slightly higher when compared to conventional techniques measurements in natural open seawater with DIC levels validated between approximately 1950 and $2200 \mu \mathrm{mol} \mathrm{kg}{ }^{-1}$ ) obtained using high precision DIC analyzers. This underscores the need for accurate experimental measurements of variables used for carbonate parameter derivations. In general, the investigated water samples showed that $A_{T}$ was relatively greater than the DIC.

Table 2. Carbonate quantities for SML and SSW samples from Lagos Lagoon

\begin{tabular}{|c|c|c|c|c|c|c|c|}
\hline $\begin{array}{l}\text { Sample } \\
\text { ID }\end{array}$ & $\begin{array}{c}\mathrm{A}_{T} \\
(\mu \mathrm{mol} / \mathrm{kgSW})\end{array}$ & $\begin{array}{c}\mathrm{TCO}_{2} \\
(\mu \mathrm{mol} / \mathrm{kgSW})\end{array}$ & 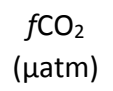 & $\begin{array}{c}\mathrm{HCO}_{3} \\
(\mu \mathrm{mol} / \mathrm{kgSW})\end{array}$ & $\begin{array}{c}\mathrm{CO}_{3}^{2-} \\
(\mu \mathrm{mol} / \mathrm{kgSW})\end{array}$ & $\begin{array}{c}\text { B Alk } \\
(\mu \mathrm{mol} / \mathrm{kgSW})\end{array}$ & $\begin{array}{c}\mathrm{OH} \\
(\mu \mathrm{mol} / \mathrm{kgSW})\end{array}$ \\
\hline $\mathrm{ST} 1_{S M L}$ & 2760.0 & 2659.8 & 521.9 & 2531.5 & 94.7 & 38.7 & 0.5 \\
\hline $\mathrm{ST} 2_{S M L}$ & 2800.0 & 2682.2 & 427.6 & 2547.0 & 106.9 & 38.6 & 0.6 \\
\hline $\mathrm{ST} 3_{S M L}$ & 2600.0 & 2559.0 & 661.5 & 2453.1 & 61.7 & 23.2 & 0.3 \\
\hline $\mathrm{ST} 4_{S M L}$ & 2700.0 & 2609.8 & 527.9 & 2487.4 & 88.1 & 35.9 & 0.5 \\
\hline $\mathrm{ST}_{S M L}$ & 2500.0 & 2441.2 & 586.8 & 2334.9 & 67.8 & 29.0 & 0.4 \\
\hline $\mathrm{STG}_{S M L}$ & 2800.0 & 2807.5 & 1035.5 & 2691.5 & 46.3 & 15.7 & 0.2 \\
\hline $\mathrm{ST}_{1}$ ssW & 2600.0 & 2464.8 & 380.8 & 2329.5 & 110.8 & 48.2 & 0.6 \\
\hline ST2 ${ }_{s S W}$ & 2650.0 & 2449.1 & 239.7 & 2277.6 & 155.8 & 60.0 & 0.9 \\
\hline ST3 ${ }_{s s w}$ & 2740.0 & 2644.6 & 521.9 & 2518.9 & 91.8 & 37.0 & 0.5 \\
\hline ST4 ssw & 2780.0 & 2499.5 & 187.5 & 2277.3 & 210.1 & 81.3 & 1.2 \\
\hline ST5 $_{\text {ssw }}$ & 2600.0 & 2513.1 & 500.0 & 2396.0 & 84.4 & 34.8 & 0.5 \\
\hline ST6 ${ }_{\text {ssw }}$ & 2840.0 & 2734.4 & 445.8 & 2603.1 & 101.4 & 33.6 & 0.5 \\
\hline
\end{tabular}




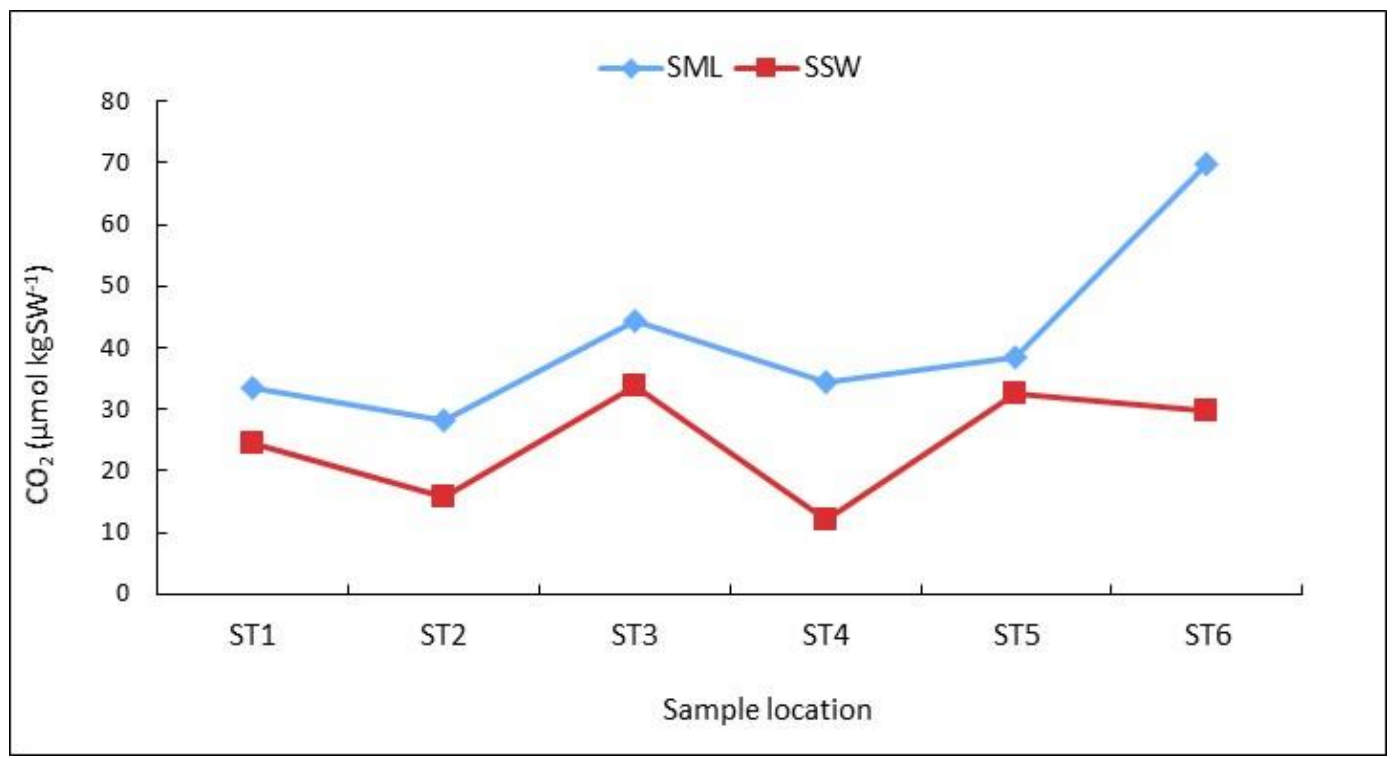

Figure 4. Aqueous $\mathrm{CO}_{2}$ in surface microlayer and subsurface water samples of Lagos Lagoon

\section{Conclusions}

Coastal and inland aquatic ecosystems are critical parts of our environment although its quality has been compromised and is under persistent threat from unregulated point and nonpoint water pollution sources. In this study, the observed levels of physicochemical parameters indicated values that are comparable to moderately polluted lagoon systems. Although the study could not pinpoint short-term pollution challenges owing to the limited number of measurements, the data suggest emerging water degradation concerns. However, the occurrence of the carbonate species was in the order $\mathrm{HCO}_{3}{ }^{-}>\mathrm{CO}_{3}{ }^{2-}>\mathrm{CO}_{2}$. The investigated water samples showed that $A_{T}$ was relatively greater than the DIC. Although the derived carbonate parameters in this study may not be entirely consistent with direct measurements using very high precision $\mathrm{CO}_{2}$ and DIC instruments, the relative usefulness of the present data may be a progenitor for future research in the studied ecosystem. This however calls for a more comprehensive and extensive long-term monitoring and assessment studies of the surface microlayer and upper mixed layer water of the Lagoon to ascertain its pollution status and inorganic carbon dynamics. This report provides useful initial data of a long-term investigation into the water quality status of the surface microlayer and upper mixed layer of the Lagoon, and also presents an inceptive study into the inorganic carbon variability and $\mathrm{CO}_{2}$ fluxes at the sea-air interface of the Lagos Lagoon. However, we strongly suggest that indiscriminate dumping of untreated sewage, industrial and biomedical wastes, and municipal effluents into the Lagoon should be discouraged.

\section{Acknowledgements}

We are grateful to NSF-START for grant assistance and Mr. John P. Uyimedu, Nigerian Institute of Oceanography and Marine Research, Lagos for technical and analytical assistance.

\section{References}

Agbaire O. and Obi C.G. (2009), Seasonal variation of some physicochemical properties of River Ethiope water in Abraka, Nigeria, Journal of Applied Environmental Management, 13(1), 55-57.

Anderson G. (2008), Seawater composition. Available at: http://www.marinebio.net/ marinescience/02ocean/swcomposition.htm (Retrieved: April 24, 2014). 
Benson N.U., Essien J.P., Asuquo F.E. and Eritobor A.L. (2014), Occurrence and distribution of polycyclic aromatic hydrocarbons in surface microlayer and subsurface seawater of Lagos Lagoon, Nigeria, Environmental Monitoring and Assessment, 186, 5519-5529, doi: 10.1007/s10661-014-3800-z

Bockmon E.E. and Dickson A.G. (2015), An inter-laboratory comparison assessing the quality of seawater carbon dioxide measurements, Marine Chemistry, 171, 36-43

Cunliffe M., Engel A., Frka S., Gašparovic' B., Guitart C., Murrell J.C., Salter M., Stolle C., Upstill-Goddard R. and Wurl O. (2013), Sea surface microlayers: a unified physicochemical and biological perspective of the air-ocean interface, Progress in Oceanography, 109, 104-116.

Del Vento S. and Dachs J. (2007), Infleunce of the surface microlayer on atmospheric deposition of aerosols and polycyclic aromatic hydrocarbons, Atmos. Environ., 41, 4920-4930.

DOE (1994), Handbook of methods for the analysis of the various parameters of the carbon dioxide system in seawater; version 2, (eds. Dickson, A.G. and Goyet, C.) ORNL/CDIAC-74.

Dickson A.G. (1990), Thermodynamics of the Dissociation of Boric Acid in Synthetic Seawater from 273.15 to $318.15 \mathrm{~K}$, Deep Sea Research Part A. Oceanographic Research Papers, 37,(5), 755-766.

Dickson A.G. and Millero F.J. (1987), A Comparison of the Equilibrium Constants for the Dissociation of Carbonic Acid in Seawater Media, Deep Sea Research Part A. Oceanographic Research Papers, 34(10), 1733-1743.

Ezeonyejiaku C.D. and Obiakor M.O. (2013), Physicochemical and Heavy Metal Profile of Surface Water, Anthropogenic Activities, and Community Health Implications, Journal of Environmental Conservation Research, 1(2), 40-48, doi:10.12966/jecr.08.05.2013.

Gioia R., Dachs J., Nizzetto L., Berrojalbiz N., Galban C., Del Vento S., Mejanelle L. and Jones K.C. (2011), Sources, transport and fate of organic pollutants in the oceanic environment. In: M. Quante et al. (eds.), Persistent Pollution - Past, present and future. Springer-Verlag Berlin Heidelberg, doi:10.1007/978-3-642-17419-3_8.

Guitart C., García-Flor N., Bayona J.M. and Albaigés J. (2007), Occurrence and fate of polycyclic aromatic hydrocarbons in the coastal surface microlayer, Marine Pollution Bulletin, 54(2), 186-194.

Gupta N., Yadav K.K., Kumar V. and Signh D. (2013), Assessment of physicochemical properties of Yamuna River in Agra City, International Journal of Chemical and Technology Research, 5, 528 - 531.

Ji H., Sheng G., Xin H. and Sha Y. (2009), Distribution of dissolved inorganic carbon (DIC) and its related parameters in seawater of the North Yellow Sea and off the Qingdao Coast in October, 2007, Journal of Ocean University of China, 8, 366-376

Lawson E.O. (2011), Physico-chemical parameters and heavy metal contents of water from the Mangrove Swamps of Lagos Lagoon, Lagos, Nigeria, Advances in Biological Research, 5(1), 08-21.

Mehrbach C., Culberson C.H., Hawley J.E. and Pytkowicz R.M. (1973), Measurement of the Apparent Dissociation Constants of Carbonic Acid in Seawater at Atmospheric Pressure, Limnology and Oceanography, 18, 897-907.

Muduli P.R., Kanuri V.V., Robin R.S., Charan Kumar B., Patra S., Raman A.V., Nageswara Rao G., Subramanian B.R. (2012), Spatio-temporal variation of $\mathrm{CO} 2$ emission from Chilika Lake, a tropical coastal lagoon, on the east coast of India, Estuarine, Coastal and Shelf Science, 113, 305-313.

Muduli P.R., Kanuri V.V., Robin R.S., Kumar B.C., Patra S., Raman A.V., Nageswara R. and Subramanian B.R. (2013), Distribution of dissolved inorganic carbon and net ecosystem production in a tropical brackish water lagoon, India, Continental Shelf Research, 64, 75-87.

Newton J.A., Feely R.A., Jewett E.B., Williamson P. and Mathis J. (2014), Global ocean acidification observing network: requirements and governance plan, http://www.goa-on.org/docs/GOA-ON_Plan_final_Sept_2014.pdf.

Omaka O.N., Nwabue F.I., Itumoh E.J., Oroke E.C. and Igwe D.O. (2014), Physicochemical parameters and nutrients variations of streams and rivers in Abakaliki, Ebonyi State, Nigeria, Global NEST Journal, 16,114-123.

Raibole M. and Singh Y.P. (2011), Impact of Physico-Chemical Parameters on Microbial Diversity: Seasonal Study, Current World Environment, 6(1), 71-76.

Raj N. and Azeez P.A. (2009), Spatial and temporal variation in surface water chemistry of a tropical river, the river Bharathapuzha, India, Current Science, 96(2), 245-251. 
Robbins L.L., Hansen M.E., Kleypas J.A. and Meylan S.C. (2010), CO2calc-A user-friendly seawater carbon calculator for Windows, Max OS X, and iOS (iPhone): U.S. Geological Survey Open-File Report 2010-1280, 17 p.

Takahashi T., Feely R.A., Weiss R.F., Wanninkhof R.H., Chipman D.W., Sutherland S.C. and Takahashi T.T. (1997), Global air-sea flux of $\mathrm{CO} 2$ : an estimate based on measurements of sea-air $\mathrm{pCO}_{2}$ difference, Proceedings of the National Academy of Sciences, 94, 8292-8299.

Thompson A. (2014), April Becomes 1st Month With $\mathrm{CO}_{2}$ Levels Above 400 ppm, http://www.climatecentral.org/news/april-becomes-first-month-with-co2-levels-above-400-ppm-17367. Accessed: 30th April, 2014.

Udosen E.D. (2001), Variations in oxygen and some related pollution parameters in some streams in Itu area of Nigeria, Journal of Environmental Sciences (China), 12(1), 75-80.

Valente J.P.S., Padilha M.M. and Silva A.M. (1997), Dissolved oxygen (DO), biochemical oxygen demand (BOD) and chemical oxygen demand (COD) as pollution parameters in the Lavapés/Botucatu-SP brook, Eclética Química, 22, 49-66.

Weiss R.F. (1974), Carbon dioxide in water and seawater: The solubility of a non-ideal gas, Marine Chemistry, 2, $203-215$.

Williams A.B. and Benson N.U. (2010), Interseasonal hydrological characteristics and variabilities in surface water of tropical estuarine ecosystems within Niger Delta, Nigeria Environmental Monitoring and Assessment, 165(1-4), 399-406, doi:10.1007/s10661-009-0955-0

Wolf-Gladrow D.A., Zeebe R.E., Klaas C., Körtzinger A. and Dickson A.G. (2007), Total alkalinity: The explicit conservative expression and its application to biogeochemical processes, Marine Chemistry, 106(1-2), 287-300 doi:10.1016/j.marchem.2007.01.006

Ya M.-L., Wang X.-H., Wu Y.-L., Ye C-X. and Li Y.-Y. (2014), Enrichment and partitioning of polycyclic aromatic hydrocarbons in the sea surface microlayer and subsurface water along the coast of Xiamen Island, China, Marine Pollution Bulletin, 78, 110-117.

Zeebe R.E. and Wolf-Gladrow D.A. (2001), $\mathrm{CO}_{2}$ in Seawater: Equilibrium, Kinetics, Isotopes. Elsevier Oceanography Series. Amsterdam.

Zeebe R. (2011), Marine carbonate chemistry. Retrieved from http://www.eoearth.org/ view/article/154468 